\title{
Morphological differences in embryos of goldfish (Carassius auratus auratus) under different incubation temperatures
}

\author{
HIROTARO URUSHIBATA*,1,2, EISUKE TAKAHASHI ${ }^{1}$, YU SHIMIZU1', TOSHIYA MIYAZAKI², \\ TAKAFUMI FUJIMOTO ${ }^{1}$, KATSUTOSHI ARAI ${ }^{1}$ and ETSURO YAMAHA ${ }^{2}$ \\ ${ }^{1}$ Nanae Freshwater Station, Field Science Center for Northern Biosphere, Hokkaido University and \\ ${ }^{2}$ Laboratory of Aquaculture Genetics and Genomics, Faculty and Graduate School of Fisheries Sciences, \\ Hokkaido University, Hokkaido, Japan
}

\begin{abstract}
The goldfish (Carassius auratus auratus) is a useful species for embryonic micromanipulations because of its large egg size and wide temperature tolerance. Here, we describe in detail the rate of development and morphological characteristics of goldfish embryos incubated at temperatures between $10^{\circ} \mathrm{C}$ and $30^{\circ} \mathrm{C}$. The cleavage speed increased rapidly as temperature increased. Synchronized cell divisions occurred at $131 \mathrm{~min}$ intervals at $10^{\circ} \mathrm{C}$, at $33 \mathrm{~min}$ intervals at $20^{\circ} \mathrm{C}$, and at $19 \mathrm{~min}$ intervals at $30^{\circ} \mathrm{C}$ during the cleavage period. The rate of hatched abnormal embryos significantly increased at temperatures of $26^{\circ} \mathrm{C}$ and above, while there was no change in the number of abnormal embryos at temperatures less than $24^{\circ} \mathrm{C}$. Moreover, the blastomeres around the center of the blastodisc rose in the direction of the animal pole at temperatures less than $14^{\circ} \mathrm{C}$. At the lower temperatures, clusters of maternally-supplied germplasm were visualized both at the ends of the first three cleavage furrows and at the border between the lower and upper tiers at the 16- to 32-cell stage, with injection of artificial mRNA and vasa in situ hybridization. This study showed that temperature affects not only developmental speed but also the shape of the blastodisc and the distribution of maternally-supplied materials in the blastodisc. By controlling the temperature, it is possible for researchers to prepare many stages of embryos and shapes of the blastodisc from a single batch of eggs.
\end{abstract}

KEY WORDS: cleavage, embryonic development, morphogenesis, normal developmental, primordial germ cell, $P G C$

\section{Introduction}

The familiar ornamental goldfish (Carassius auratus auratus) has often been used in experiments of reproductive and developmental biology. For example, bisection at the early cleavage stage of goldfish resulted in the distribution of dorsal maternal factor(s) in the vegetal yolk hemisphere (Mizuno et al., 1997). Graft transplantation showed that at the blastula stage, blastoderm cells are highly pluripotent (Kazama-Wakabayashi et al., 1999, Mizuno et al., 1997), and the yolk syncytial layer has mesoderm-inducing activity (Yamaha et al., 1998). In addition, triploid and gynogenetic diploid embryos are easily induced in goldfish by inhibiting the second polar-body release with heat-shock treatment just after fertilization with normal and irradiated sperm, respectively. Germline chimera has been successfully produced in goldfish by transplantation of blastula graft (Yamaha et al., 2001, Yamaha et al., 2003) and using primordial germ cells (PGCs) (Goto et al., 2012). These achievements suggest that goldfish eggs and embryos should have characteristics useful for micromanipulation and handling, such as easy artificial ovulation, easy dechorionation, relatively large egg size, and relatively tough chorion, as compared with other experimental model fish, such as the zebrafish Danio rerio. It is difficult to slow down developmental speed in zebrafish. Goldfish embryos are also able to survive and develop under a wide range of temperatures. Therefore, the goldfish has the potential to be an excellent host species for studying the interactions between donor germ cells and host somatic cells.

A clear description of each stage of embryonic development is vital to implement embryonic manipulation successfully. The

Abbreviations used in this paper: dpf, days post-fertilization; gfp, green fluorescent protein; hpf, hours post-fertilization; PGC, primordial germ cell.

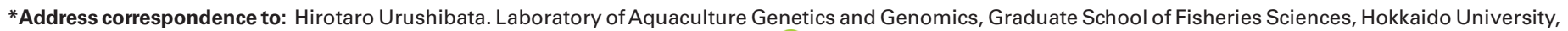
Hakodate, Hokkaido 041-8611, Japan. E-mail: hirotaro.urushibata @ gmail.com - (iD https://orcid.org/0000-0002-3546-8434
}

Supplementary Material (four figures) for this paper is available at: https://doi.org/10.1387/ijdb.190144hu 
developmental stages of model animals have been described in great detail especially in zebrafish and medaka Oryzias latipes (Iwamatsu, 2004, Kimmel et al., 1995). In goldfish, the developmental stages before gastrulation of embryos incubated at $20^{\circ} \mathrm{C}$ were defined by Yamaha et al., (1999), and the stages before hatching at $24^{\circ} \mathrm{C}$ by Tsai et al., (2013). However, as the incubation temperature differed in those two studies, it is difficult to determine the speed of development based on external appearance of the embryos.

Medaka embryos can develop at temperatures ranging from 14 to $34^{\circ} \mathrm{C}$. Because the unfertilized eggs of that species can be kept at low temperatures, time-consuming manipulation, such as nuclear transplantation, can be successfully performed with sufficient time (Wakamatsu, 2008). Medaka embryos are also important as educational materials for successive observations of embryogenesis owing to easy preparation of embryos at various stages as induced by different temperatures. Goldfish embryos also develop under a range of temperatures, from 10 to $30^{\circ} \mathrm{C}$. However, the developmental staging of goldfish has not been described for incubation under different temperatures.

Here, we describe the developmental stages of goldfish, up to $100 \%$ epiboly, under different incubation temperatures, ranging from 10 to $30^{\circ} \mathrm{C}$. The stages of embryonic development from epiboly to hatching at $20^{\circ} \mathrm{C}$ are described in particular detail for comparison with the stages under $24^{\circ} \mathrm{C}$ as described in Tsai et al., (2013). We observed embryonic development at temperatures from 10 to $30^{\circ} \mathrm{C}$. Incubation under lower temperatures affected the early cleavage pattern and distribution of the germplasm. The results are helpful not only in studies of micromanipulation using goldfish embryos before the late blastula stage, but also for making detailed descriptions of the external appearance of embryos at each developmental stage.

\section{Results}

\section{Embryonic development}

The developmental stages of goldfish embryos incubated at $20^{\circ} \mathrm{C}$ are summarized in Table 1 , and given in comparison with descriptions of their development under $24^{\circ} \mathrm{C}$ as reported by Tsai

A

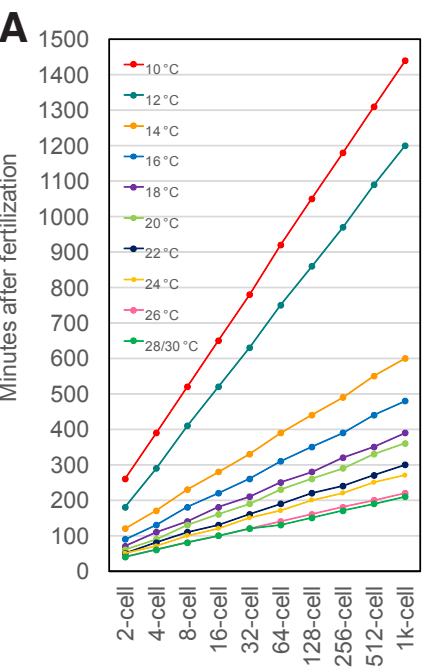

Developmental stage

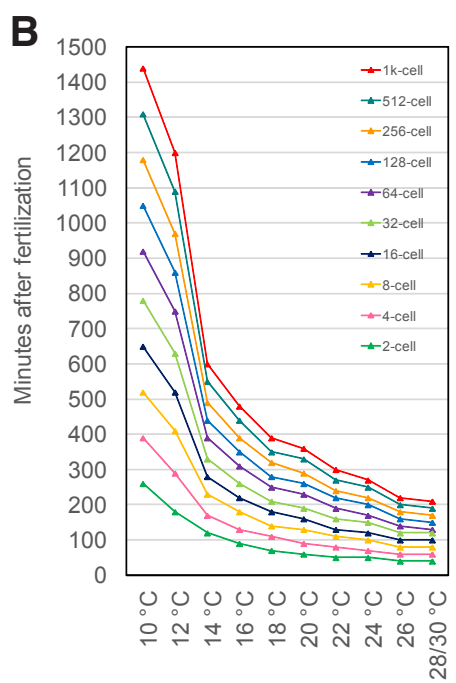

Incubation temperature

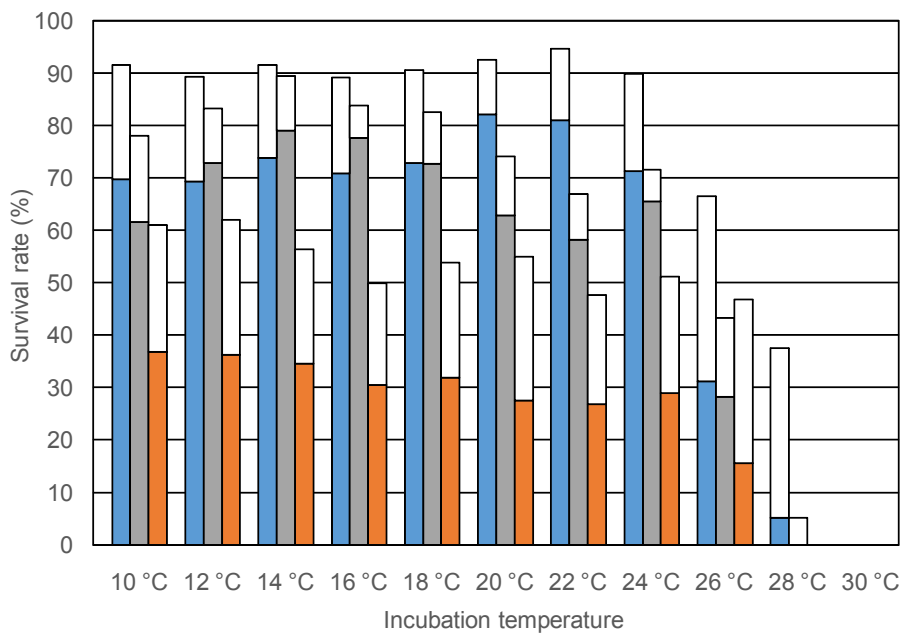

Fig. 2. Survival rate of goldfish embryos incubated at different temperatures. Three batches of embryos (represented by blue, grey, and orange bars) were incubated at each different temperature during the cleavage stage, and then transferred to $20^{\circ} \mathrm{C}$; colors indicate normal embryos, and white bars indicate abnormal embryos. Embryos were checked for abnormalities at 5 days post-fertilization.

et al., (2013). As the chorion of goldfish eggs is opaque, dechorionated eggs were used to describe each developmental stage. The embryonic period was subdivided into several stages following Fujimoto et al., (2006). Each developmental stage was named using morphological features in accordance with the stages for zebrafish (Kimmel et al., 1995). Embryonic development of the goldfish was divided into five periods (Table 1): cleavage, blastula, gastrula (Supplementary Fig. S1), segmentation, and hatching (Supplementary Fig. S2). Somite number increased on average by three pairs every $2 \mathrm{~h}$ (Supplementary Fig. S3). Hatching in the earliest batch was first observed at $96 \mathrm{hpf}$, and finished at 138 hpf. Another batch started hatching at the same time, but did not finish until $180 \mathrm{hpf}$ (Supplementary Fig. S4). Fifty percent of the embryos hatched between 114 and $180 \mathrm{hpf}$. At $20^{\circ} \mathrm{C}$, the average hatching time for the three batches was $120 \mathrm{hpf}$.

\section{Development under different temperatures}

Based on embryo morphology under $20^{\circ} \mathrm{C}$, the developmental rate to $100 \%$ epiboly was determined for different temperatures ranging from 10 to $30^{\circ} \mathrm{C}$ (Table 2, Fig. 1). Incubated embryos developed rapidly at higher temperatures $\left(>20^{\circ} \mathrm{C}\right)$ and slowly at lower temperatures $\left(<20^{\circ} \mathrm{C}\right)$. The rate of cell division during early development (before the midblastula transition [MBT]) increased proportionally with increasing temperature (Fig. 1A). Cell division during cleavage was synchronized and occurred at $131 \mathrm{~min}$ intervals at $10^{\circ} \mathrm{C}, 33$ min intervals at $20^{\circ} \mathrm{C}$, and 19 min intervals at $30^{\circ} \mathrm{C}$. Between development at the lowest $\left(10^{\circ} \mathrm{C}\right)$ and highest $\left(30^{\circ} \mathrm{C}\right.$ ) temperatures, there was a difference of $220 \mathrm{~min}$ (about 3.7 h) at the 2-cell stage, 1,230 $\mathrm{min}(20.5 \mathrm{~h})$ at the $1 \mathrm{k}$-cell stage (i.e. MBT), and 1,690 min (about $28 \mathrm{~h}$ ) at the late-blastula stage. The time taken from fertilization to each cell division during cleavage

Fig. 1. Rates of development in goldfish embryos incubated at different temperatures. (A) Plot of the time for goldfish embryos to reach each embryonic stage under different cultivation temperatures, and(B) plot of time against temperature for embryos at each stage of development. 
decreased exponentially with a change in temperature from 14 to $30^{\circ} \mathrm{C}$ (Fig. 1B). The time taken for each cell division was relatively long at temperatures of $10-14^{\circ} \mathrm{C}$ (Fig. 1B).

\section{Frequency of abnormal development at different temperatures}

The effect of different temperatures on subsequent development was assessed. Embryos incubated at different temperatures were transferred to $20^{\circ} \mathrm{C}$ after the $1 \mathrm{k}$-cell stage, and the survival rate and frequency of abnormality, namely body curvature or short body were examined at $5 \mathrm{dpf}$ (Fig. 2). The lowest number of abnormalities was found in embryos incubated at $20^{\circ} \mathrm{C}$. As the temperature increased, the number of abnormal embryos at the hatching stage significantly increased. At temperatures of $>26^{\circ} \mathrm{C}$, more than half of the embryos were abnormal $\left(20^{\circ} \mathrm{C}\right.$ : $11.2 \%, 15.2 \%$ and $50.0 \%$, $26^{\circ} \mathrm{C}: 53.1 \%, 34.8 \%$ and $66.7 \%$ ). The frequency of abnormalities did not commensurately increase at temperatures of $<20^{\circ} \mathrm{C}$, as compared with those kept at $>26^{\circ} \mathrm{C}$.

\section{External appearance of embryos incubated at lower temperatures}

The shape of the blastodisc differed between embryos incubated at the lower and higher temperatures. The blastodisc was round in embryos incubated at the lower temperatures $\left(<14^{\circ} \mathrm{C}\right)$, and flat in embryos incubated at the higher temperatures $\left(>14^{\circ} \mathrm{C}\right)$ (Fig. 3). The height of the blastodisc decreased with increasing temperatures, whereas the width increased with increasing temperatures (Fig. 4).

Early cleavage patterns were altered in embryos incubated at $10^{\circ} \mathrm{C}$. In the 16 -cell stage, the fourth cleavage at $10^{\circ} \mathrm{C}$ differed from

TABLE 1

DEVELOPMENTAL STAGES OF GOLDFISH EMBRYOS AT $20^{\circ} \mathrm{C}$

\begin{tabular}{|c|c|c|c|}
\hline Stage name & Time $\left(20^{\circ} \mathrm{C}\right)^{\mathrm{a}}$ & Tsai et al., $2013\left(24^{\circ} \mathrm{C}\right)^{\mathrm{b}}$ & Characteristics \\
\hline \multicolumn{4}{|l|}{ Cleavage period } \\
\hline 1-cell & $40 \min$ & $0 \mathrm{~min}$ & Formation of the blastodisc on the animal pole \\
\hline 1st cleavage & $50 \mathrm{~min}$ & & Beginning of first cleavage \\
\hline 2-cell & $1 \mathrm{~h}$ & $24 \min$ & The first cleavage furrow \\
\hline 4-cell & $1 \mathrm{~h} 30 \mathrm{~min}$ & $51 \mathrm{~min}$ & The blastodisc formed by $2 \times 2$ array blastomeres \\
\hline 8-cell & $2 \mathrm{~h} 10 \mathrm{~min}$ & $1 \mathrm{~h} 18 \mathrm{~min}$ & Formed by $2 \times 4$ array blastomeres \\
\hline 16-cell & $2 \mathrm{~h} 40 \mathrm{~min}$ & $1 \mathrm{~h} 45 \mathrm{~min}$ & Formed by $4 \times 4$ array blastomeres \\
\hline 32-cell & $3 \mathrm{~h} 10 \mathrm{~min}$ & $2 \mathrm{~h} 12 \min$ & The fifth horizontal cleavage in the monolayered blastomeres \\
\hline 64-cell & $3 \mathrm{~h} 50 \mathrm{~min}$ & $2 \mathrm{~h} 39 \mathrm{~min}$ & Uncountable blastomeres \\
\hline \multicolumn{4}{|l|}{ Early blastula period } \\
\hline 128-cell & $4 \mathrm{~h} 20 \mathrm{~min}$ & $3 \mathrm{~h} 6 \mathrm{~min}$ & \\
\hline 256-cell & $4 \mathrm{~h} 50 \mathrm{~min}$ & $3 \mathrm{~h} 33 \mathrm{~min}$ & \\
\hline 512-cell & $5 \mathrm{~h} 30 \mathrm{~min}$ & $4 \mathrm{~h}$ & \\
\hline $1 \mathrm{k}$-cell & $6 \mathrm{~h}$ & $4 \mathrm{~h} 27 \mathrm{~min}$ & Mid-Blastula transition, E-YSL formation \\
\hline \multicolumn{4}{|l|}{ Late blastula period } \\
\hline Oblong & $8 \mathrm{~h}$ & $5 \mathrm{~h} 21 \mathrm{~min}$ & I-YSL formation, ellipsodial shape \\
\hline Sphere & $10 \mathrm{~h}$ & $5 \mathrm{~h} 48 \mathrm{~min}$ & Spherical shape \\
\hline Dome & $10 \mathrm{~h} 30 \mathrm{~min}$ & $6 \mathrm{~h} 15 \mathrm{~min}$ & Beginning of epiboly, bulging \\
\hline $30 \%$ epiboly & $11 \mathrm{~h}$ & $6 \mathrm{~h} 42 \mathrm{~min}$ & Progress of epiboly, $30 \%$ coverage of a yolk by the blastoderm \\
\hline \multicolumn{4}{|l|}{ Gastrula period } \\
\hline $50 \%$ epiboly & $12 \mathrm{~h}$ & $8 \mathrm{~h}$ & Half coverage of a yolk cell \\
\hline Germ ring & $13 \mathrm{~h}$ & $8 \mathrm{~h} 30 \mathrm{~min}$ & Arrest of the epoliboly, germ ring \\
\hline Embryonic shield & $13 \mathrm{~h} 30 \mathrm{~min}$ & $8 \mathrm{~h} 36 \mathrm{~min}$ & Formation of an embryonic shield \\
\hline $70 \%$ epiboly & $16 \mathrm{~h}$ & & $70 \%$ coverage of a yolk cell \\
\hline $90 \%$ epiboly & $18 \mathrm{~h}$ & $11 \mathrm{~h}$ & $90 \%$ coverage of a yolk cell, yolk plug \\
\hline $100 \%$ epiboly & $20 \mathrm{~h}$ & $12 \mathrm{~h}$ & Completion of coverage, tail bud \\
\hline \multicolumn{4}{|l|}{ Segmentation period } \\
\hline 1 3-somite & $24 \mathrm{~h}$ & & $\mathrm{EL}=2.1 \mathrm{~mm}$, first somatic furrow, optic primordium \\
\hline 4 6-somite & $26 \mathrm{~h}$ & $14 \mathrm{~h}$ & $\mathrm{EL}=2.1 \mathrm{~mm}$, a horizontal crease in the optic primordium, Kupffer's vesicle \\
\hline 7 9-somite & $28 \mathrm{~h}$ & & $\mathrm{EL}=2.1 \mathrm{~mm}$ \\
\hline 10 12-somite & $30 \mathrm{~h}$ & $16 \mathrm{~h}$ & $\mathrm{EL}=2.1 \mathrm{~mm}$ \\
\hline 13 15-somite & $32 \mathrm{~h}$ & $20 \mathrm{~h}$ & $\mathrm{EL}=2.1 \mathrm{~mm}$, otic placode \\
\hline 16 18-somite & $34 \mathrm{~h}$ & & $\mathrm{EL}=2.5 \mathrm{~mm}, \mathrm{HTA}=140^{\circ}, \mathrm{OVL}=0.25 \mathrm{~mm}$, otic vesicle, formation of yolk extension \\
\hline 19 21-somite & $36 \mathrm{~h}$ & & $\mathrm{EL}=2.9 \mathrm{~mm}, \mathrm{HTA}=140^{\circ}, \mathrm{OVL}=0.25 \mathrm{~mm}$, optic cup and lens placode \\
\hline 30-somite & $42 \mathrm{~h}$ & & $\mathrm{EL}=3.3 \mathrm{~mm}, \mathrm{HTA}=105^{\circ}, \mathrm{OVL}=0.20 \mathrm{~mm}$, completion of somites, weak heartbeat \\
\hline \multicolumn{4}{|c|}{ Post segmentation period } \\
\hline $2 \mathrm{dpf}$ & $48 \mathrm{~h}$ & & $\mathrm{EL}=5.0 \mathrm{~mm}, \mathrm{HTA}=105^{\circ}, \mathrm{OVL}=0.15 \mathrm{~mm}$, otolith, median fin fold, early pigment in retina and skin \\
\hline $3 \mathrm{dpf}$ & $72 \mathrm{~h}$ & & $\mathrm{EL}=5.8 \mathrm{~mm}, \mathrm{HTA}=80^{\circ}, \mathrm{OVL}=0.10 \mathrm{~mm}, \mathrm{PF}(\mathrm{H} / \mathrm{W})=1.0$, pectral fin, anus \\
\hline $4 \mathrm{dpf}$ & $96 \mathrm{~h}$ & & $\mathrm{EL}=7.0 \mathrm{~mm}, \mathrm{HTA}=45^{\circ}, \mathrm{PF}(\mathrm{H} / \mathrm{W})=2.0$ \\
\hline \multicolumn{4}{|l|}{ Hatching period } \\
\hline $5 \mathrm{dpf}$ & $120 \mathrm{~h}$ & & $\mathrm{EL}=8.1 \mathrm{~mm}, \mathrm{HTA}=30^{\circ}, \mathrm{PF}(\mathrm{H} / \mathrm{W})=3.5$, hatch \\
\hline
\end{tabular}

EL, embryo length; HTA, head-trunk angle; OVL, otic vesicle length; PF, pectoral fin; H/W, height/width.

aHours and minutes after fertilization.

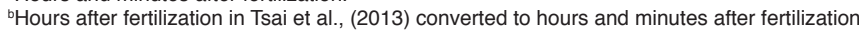


TABLE 2

DEVELOPMENTAL SPEEDS OF GOLDFISH EMBRYOS UNDER DIFFERENT TEMPERATURE CONDITIONS

\begin{tabular}{|c|c|c|c|c|c|c|c|c|c|c|c|}
\hline \multirow[b]{2}{*}{ Stage } & \multicolumn{11}{|c|}{ Incubation temperature } \\
\hline & $\begin{array}{c}10^{\circ} \mathrm{C} \\
\text { (h: } \min )\end{array}$ & $\begin{array}{c}12^{\circ} \mathrm{C} \\
\text { (h: } \min )\end{array}$ & $\begin{array}{c}14^{\circ} \mathrm{C} \\
\text { (h: } \min )\end{array}$ & $\begin{array}{c}16^{\circ} \mathrm{C} \\
(\mathrm{h}: \mathrm{min})\end{array}$ & $\begin{array}{c}18^{\circ} \mathrm{C} \\
(\mathrm{h}: \mathrm{min})\end{array}$ & $\begin{array}{c}20^{\circ} \mathrm{C} \\
\text { (h: } \mathrm{min})\end{array}$ & $\begin{array}{c}22^{\circ} \mathrm{C} \\
\text { (h: } \min )\end{array}$ & $\begin{array}{c}24^{\circ} \mathrm{C} \\
\text { (h: } \min )\end{array}$ & $\begin{array}{c}26^{\circ} \mathrm{C} \\
\text { (h: } \min )\end{array}$ & $\begin{array}{c}28^{\circ} \mathrm{C} \\
\text { (h: } \min )\end{array}$ & $\begin{array}{c}30^{\circ} \mathrm{C} \\
\text { (h: } \min )\end{array}$ \\
\hline Cleavage speed ${ }^{\star}$ & $2: 11$ & $1: 53$ & $0: 53$ & $0: 43$ & $0: 36$ & $0: 33$ & $0: 28$ & $0: 24$ & $0: 20$ & $0: 19$ & $0: 19$ \\
\hline 2-cell & $4: 20$ & $3: 00$ & $2: 00$ & $1: 30$ & $1: 10$ & $1: 00$ & $0: 50$ & $0: 50$ & $0: 40$ & $0: 40$ & $0: 40$ \\
\hline 4-cell & $6: 30$ & $4: 50$ & $2: 50$ & $2: 10$ & $1: 50$ & $1: 30$ & $1: 20$ & $1: 10$ & $1: 00$ & $1: 00$ & $1: 00$ \\
\hline 8-cell & $8: 40$ & $6: 50$ & $3: 50$ & $3: 00$ & $2: 20$ & $2: 10$ & $1: 50$ & $1: 40$ & $1: 20$ & $1: 20$ & $1: 20$ \\
\hline 16-cell & $10: 50$ & $8: 40$ & $4: 40$ & $3: 40$ & $3: 00$ & $2: 40$ & $2: 10$ & $2: 00$ & $1: 40$ & $1: 40$ & $1: 40$ \\
\hline 32-cell & $13: 00$ & $10: 30$ & $5: 30$ & $4: 20$ & $3: 30$ & $3: 10$ & $2: 40$ & $2: 30$ & $2: 00$ & $2: 00$ & $2: 00$ \\
\hline 64-cell & $15: 20$ & $12: 30$ & $6: 30$ & $5: 10$ & $4: 10$ & $3: 50$ & $3: 10$ & $2: 50$ & $2: 20$ & $2: 10$ & $2: 10$ \\
\hline 128-cell & $17: 30$ & $14: 20$ & $7: 20$ & $5: 50$ & $4: 40$ & $4: 20$ & $3: 40$ & $3: 20$ & $2: 40$ & $2: 30$ & $2: 30$ \\
\hline 256-cell & $19: 40$ & $16: 10$ & $8: 10$ & $6: 30$ & $5: 20$ & $4: 50$ & 4:00 & $3: 40$ & $3: 00$ & $2: 50$ & $2: 50$ \\
\hline 512-cell & $21: 50$ & $18: 10$ & $9: 10$ & $7: 20$ & $5: 50$ & $5: 30$ & $4: 30$ & $4: 10$ & $3: 20$ & $3: 10$ & $3: 10$ \\
\hline $1 \mathrm{k}$-cell & $24: 00$ & $20: 00$ & $10: 00$ & $8: 00$ & $6: 30$ & $6: 00$ & $5: 00$ & $4: 30$ & $3: 40$ & $3: 30$ & $3: 30$ \\
\hline Oblong & $32: 00$ & $26: 00$ & $14: 00$ & $11: 00$ & 9:00 & $8: 00$ & $6: 30$ & $5: 30$ & $4: 10$ & 4:00 & $3: 50$ \\
\hline Sphere & $40: 00$ & $32: 00$ & $18: 00$ & $14: 00$ & $11: 30$ & $10: 00$ & $8: 00$ & $6: 50$ & $5: 20$ & $5: 10$ & $4: 50$ \\
\hline Dome & $42: 00$ & $33: 30$ & 19:00 & $14: 50$ & $12: 10$ & $10: 30$ & $8: 20$ & $7: 00$ & $5: 40$ & $5: 20$ & $5: 10$ \\
\hline $30 \%$ epiboly & $44: 00$ & $35: 00$ & $20: 00$ & $15: 30$ & $12: 50$ & $11: 00$ & $8: 50$ & $7: 20$ & $5: 50$ & $5: 40$ & $5: 20$ \\
\hline $50 \%$ epiboly & 48:00 & $38: 00$ & $22: 00$ & $17: 00$ & $14: 00$ & $12: 00$ & $9: 30$ & $8: 00$ & $6: 30$ & $6: 10$ & $5: 50$ \\
\hline Germ ring & $52: 00$ & 41:00 & $24: 00$ & $18: 30$ & $15: 20$ & $13: 00$ & $10: 20$ & $8: 40$ & 7:00 & $6: 40$ & $6: 20$ \\
\hline Embryonic shield & $54: 00$ & $42: 30$ & $25: 00$ & $19: 20$ & $15: 50$ & $13: 30$ & $10: 40$ & 9:00 & $7: 20$ & 7:00 & $6: 40$ \\
\hline $70 \%$ epiboly & $64: 00$ & $50: 00$ & $30: 00$ & $23: 00$ & 19:00 & $16: 00$ & $12: 30$ & $10: 30$ & $8: 40$ & $8: 20$ & $8: 00$ \\
\hline $90 \%$ epiboly & $72: 00$ & $56: 00$ & $34: 00$ & $26: 00$ & $21: 30$ & $18: 00$ & $14: 00$ & $11: 50$ & $9: 50$ & $9: 30$ & 9:00 \\
\hline $100 \%$ epiboly & $80: 00$ & $62: 00$ & $38: 00$ & 29:00 & $24: 00$ & $20: 00$ & $15: 30$ & $13: 00$ & $11: 00$ & $10: 30$ & $10: 00$ \\
\hline
\end{tabular}

${ }^{*}$ Cleavage speed means an average interval from 2-cell stage to $1 \mathrm{k}$-cell stage.

that at $20^{\circ} \mathrm{C}$. The first latitudinal cleavage appeared sooner, in the 16-cell stage at $10^{\circ} \mathrm{C}$ as compared with in the 64 -cell stage at $20^{\circ} \mathrm{C}$ (Fig. 5). The blastomeres around the center of the blastodisc rose in the direction of the animal pole and formed a multilayer (Fig. $5)$. The stage at which the multilayer first appeared was related to temperature (Fig. 6). At $10-14^{\circ} \mathrm{C}$, a blastodisc with a multilayer first appeared in the 16-cell stage, while a multilayer first appeared in the 64-cell stage in embryos incubated at $18-20^{\circ} \mathrm{C}$. When a single blastomere in the upper layer was injected with fluorescein isothiocyanate (FITC), the dye was maintained in the descendent cells without any diffusion to neighboring blastomeres, indicating that the injected blastomere was isolated (Fig. 7).

\section{Germplasm aggregation pattern at different temperatures}

In several fish species, such as ice goby Leucopsarion petersii and pond smelt Hypomesus olidus, it was reported that germplasm aggregated between the upper and lower tiers of the blastomeres (Saito et al., 2004, Takahashi et al., 2017). To confirm the distribution of the germplasm under cultivation at $10^{\circ} \mathrm{C}$, GFP-buc mRNA was injected into fertilized embryos at 1-cell stage, thereafter cultivated at $10^{\circ} \mathrm{C}$ and $20^{\circ} \mathrm{C}$, visualized GFP signals in 16-cell embryos were observed in the area around the margin of the blastodisc; however, GFP signals in embryos cultured at $10^{\circ} \mathrm{C}$ were distributed not only in the marginal area, but also in the boundary between the upper and lower layers (Table 3, Fig. 8). When in situ hybridization against vasa mRNA was performed, positive signals were detected at both ends of the early cleavage furrows and at the boundary between the upper and lower tiers of the blastomeres (Fig. 8). In many of the embryos kept at $10^{\circ} \mathrm{C}$, blastomeres, which were stained with a mottled pattern, were observed with vasa in situ hybridization as proof (Fig. 8).

\section{Discussion}

\section{Developmental characteristics of goldfish compared with other species}

The embryonic development of goldfish under different temperatures was previously described by Tsai et al., (2013). In this study, we described the developmental stages of goldfish from fertilization to hatching, using dechorionated embryos incubated at $20^{\circ} \mathrm{C}$. Morphological features, organogenesis, and the head-trunk angle (HTA) (Kimmel et al., 1995) were used to define the different embryonic stages. The sequence of development that we observed did not differ from that reported for goldfish by other authors (Tsai et al., 2013), however the rate of development varied with temperature. The developmental stages described for zebrafish (Kimmel et al., 1995) are similar to those observed in goldfish, although the timing of differentiation, such as the development of otoliths, median-fin folds, and pigmentation, all differed. These differences may relate to numbers of somites and the body proportions of adult fish, although both species belong to the Cyprinidae. Developmental sequences of the loach Misgurnus anguillicaudatus (Fujimoto et al., 2006), a species of Cobitidae, differed considerably from the goldfish in regard to the larger numbers of somites.

TABLE 3

\section{THE NUMBER OF GFP SIGNALS IN 16-CELL EMBRYOS AT $10^{\circ} \mathrm{C}$ INJECTED WITH GFP-BUC mRNA}

\begin{tabular}{cc}
\hline No. of GFP signals in each embryo & Average \\
(No. of GFP signals in the boundary between the upper and lower layers) & \\
$1(0), 1(0), 1(0), 1(1), 1(1), 1(1), 1(1), 2(0), 2(2), 3(0)$, & \\
$3(1), 3(1), 3(1), 3(2), 3(2), 3(3), 4(0), 4(0), 4(1), 4(2)$ & $2.4(0.95)$ \\
\hline
\end{tabular}



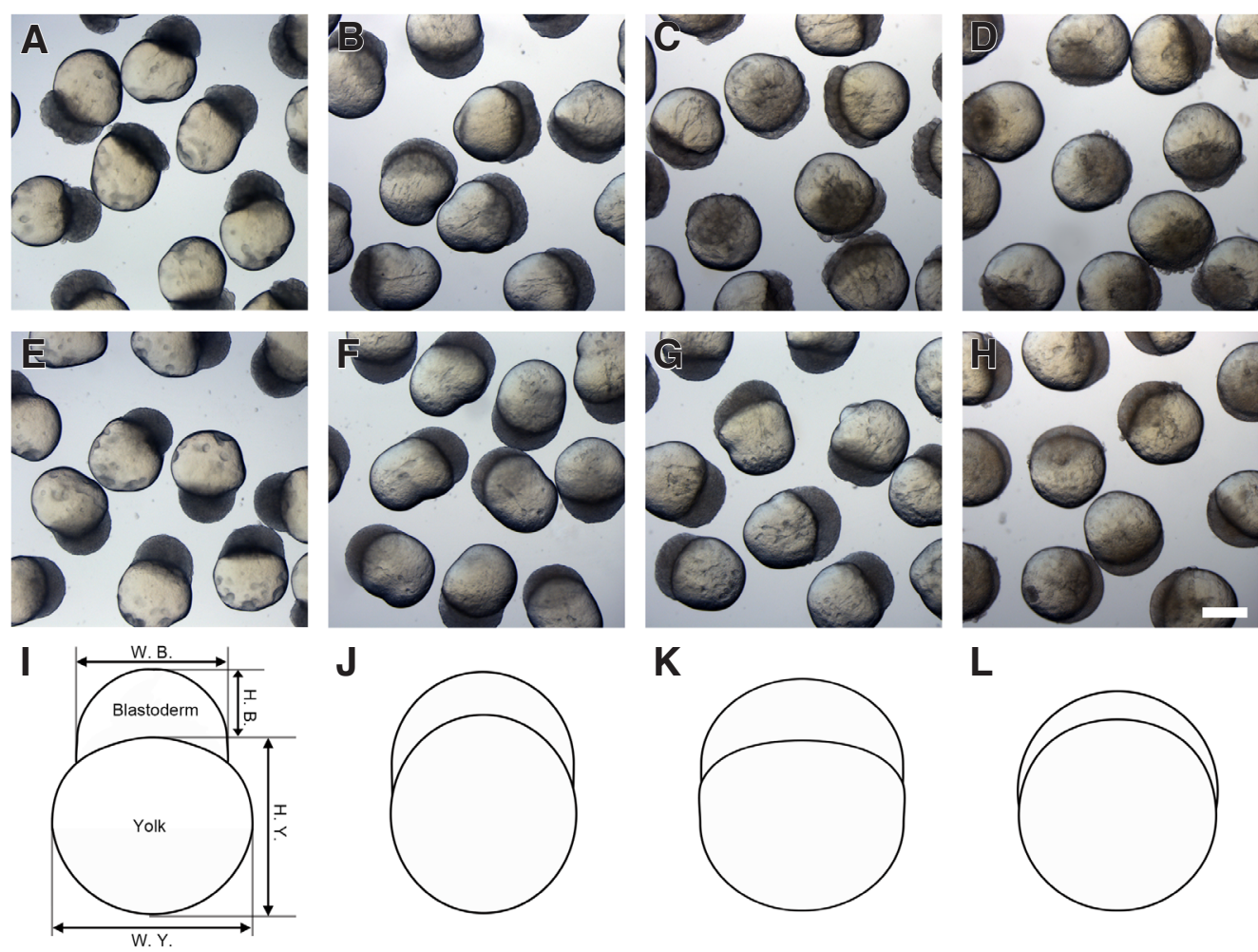

$\mathrm{J}$
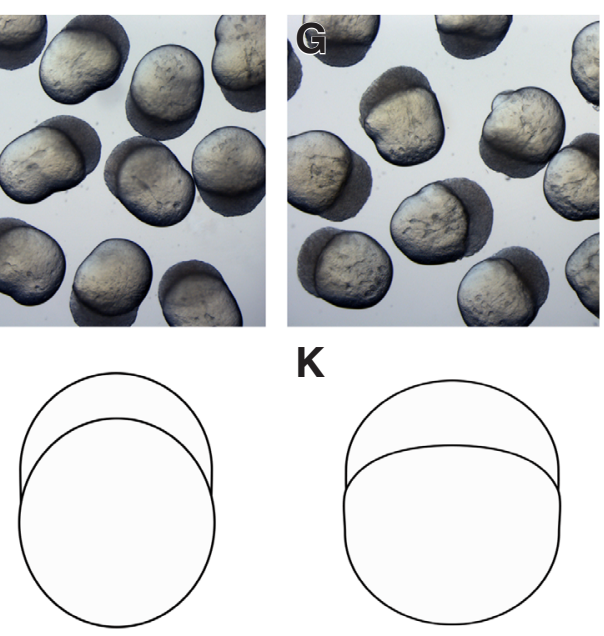

$\mathrm{K}$

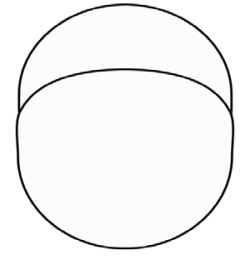

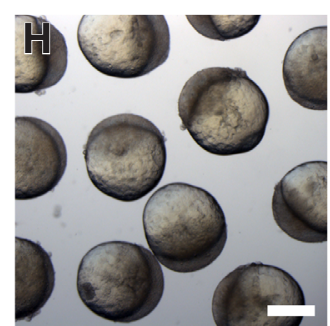

$\mathbf{L}$

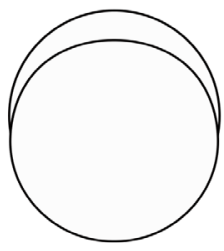

Fig. 3. (A-H) 3D images of blastodisc morphology in goldfish embryos incubated at different temperatures. (A-D) 128-cell stage. (E-H) 1 k-cell stage. Embryos in $(A)$ and $(E)$ were incubated at $10^{\circ} \mathrm{C} ;(\mathrm{B})$ and $(\mathrm{F})$ at $20^{\circ} \mathrm{C} ;(\mathrm{C})$ and $(\mathrm{G})$ at $26^{\circ} \mathrm{C}$; and $(\mathrm{D})$ and $(\mathrm{H})$ at $30^{\circ} \mathrm{C}$. Scale bar $=500 \mu \mathrm{m}$. (I-L) Schematic illustrations of goldfish embryos at the $1 \mathrm{k}$-cell stage, at representative temperatures. (I) at $10^{\circ} \mathrm{C}$; (J) at $20^{\circ} \mathrm{C}$; (K) at $26^{\circ} \mathrm{C}$; and (L) at $30^{\circ} \mathrm{C}$. Abbreviations: W.B., width of the blastodisc along the dorsalventral pole axis; H.B., height of the blastodisc along the animal-vegetalpole axis; W.Y., width of the yolk cell along the dorsal-ventral axis, with the yolk diameter measured through the equatorial plane; H.Y., height of the yolk cell along the dorsal-ventral axis, with the yolk diameter measured parallel to the animal-vegetal axis.

temperatures and high hydrostatic pressure can cause depolymerization of tubulin filaments, affecting dorso-ventral specification, and

\section{Developmental characteristics at different temperatures}

The external appearance of goldfish embryos and the timing of the first latitudinal cleavage differed between those incubated at low $\left(<14^{\circ} \mathrm{C}\right)$ and high $\left(>14^{\circ} \mathrm{C}\right)$ temperatures. Temperature altered the blastodisc height and the cleavage pattern of goldfish embryos in this study. Cytoplasmic structure is supported by microtubules and/or microfilaments that make up the cytoskeleton (Beams et al., 1985). There are many microtubules around the cortex of fertilized eggs in zebrafish. When the cytoskeleton is disrupted, abnormalities are induced in subsequent stages. High

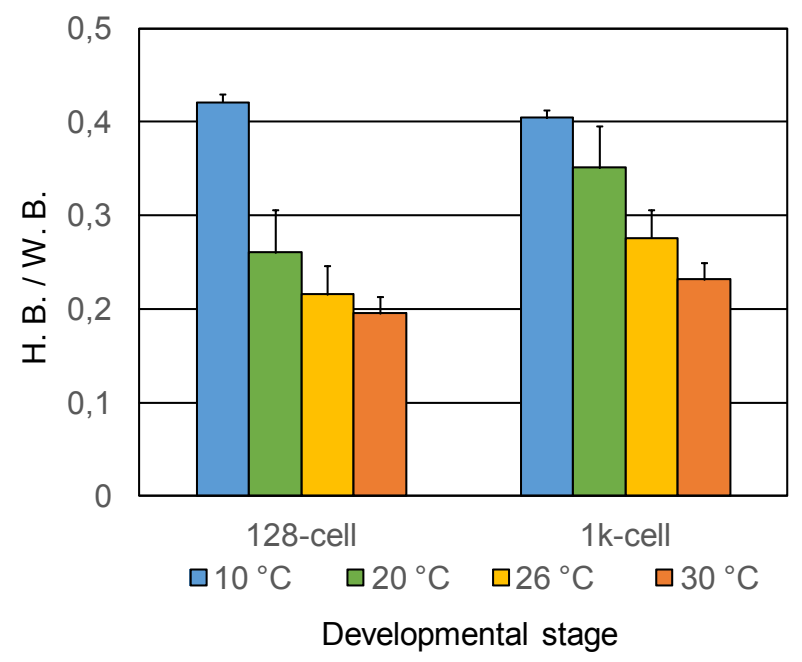

Fig. 4. The ratio that compares H.B. to W.B. in goldfish embryos at 128- and $1 \mathrm{k}$-cell stages at temperatures ranging from 10 to $30^{\circ} \mathrm{C}$. H.B., height of the blastodisc along the animal-vegetal-pole axis; W.B., width of the blastodisc along the dorsal-ventral pole axis. Bars denote standard error. resulting in the occurrence of rotational symmetry, microcephaly, a truncated head, or cyclops embryos (Yamaha et al., 2002). In the toad Xenopus laevis the microtubular density decreased at a low temperature (Alvarez and Fadic, 1992). In the present study, the time from fertilization to each cleavage stage in goldfish embryos took longer at the lower temperatures $\left(10-14^{\circ} \mathrm{C}\right)$. The kinetics of tubulin polymerization in goldfish may change at 16 - and 32 -cell stage at $10-14^{\circ} \mathrm{C}$ in contrast to $20^{\circ} \mathrm{C}$. Therefore, the morphological changes observed in goldfish embryos may be related to changes in tubulin polymerization as a result of changes in temperature.

In medaka the rate of development was altered with incubation temperature (Iwamatsu, 2004). Medaka embryos survive at temperatures up to $40^{\circ} \mathrm{C}$, but development occurs most rapidly at $34^{\circ} \mathrm{C}$. The relationship between temperature and incubation period under $34^{\circ} \mathrm{C}$ for this species is not proportional but exponential. By changing the incubation temperature, developmental speed can be controlled. In goldfish, developmental speeds during the cleavage stage also increased exponentially with increasing incubation temperatures of up to $30^{\circ} \mathrm{C}$. There was little difference in the rates of development at $10^{\circ} \mathrm{C}$ and $12^{\circ} \mathrm{C}$.

The longer incubation period at lower temperatures had little effect on the survival rate of fertilized eggs, in contrast with incubation at higher temperatures. Although the external appearance of blastulastage embryos differed at $10^{\circ} \mathrm{C}$ and $20^{\circ} \mathrm{C}$, these characteristics changed and epiboly could conclude normally.

\section{Germplasm localization}

In the present study, GFP signals after injection with GFP-buc mRNA and vasa signals following in situ hybridization were both detected at the boundaries between the lower and upper tiers of blastomeres at the 16- to 32 -cell stages in embryos kept at $10^{\circ} \mathrm{C}$. In bony fishes, PGCs originated from cells in the maternal cytoplasm, and germplasm aggregated at the site of early cleavage 

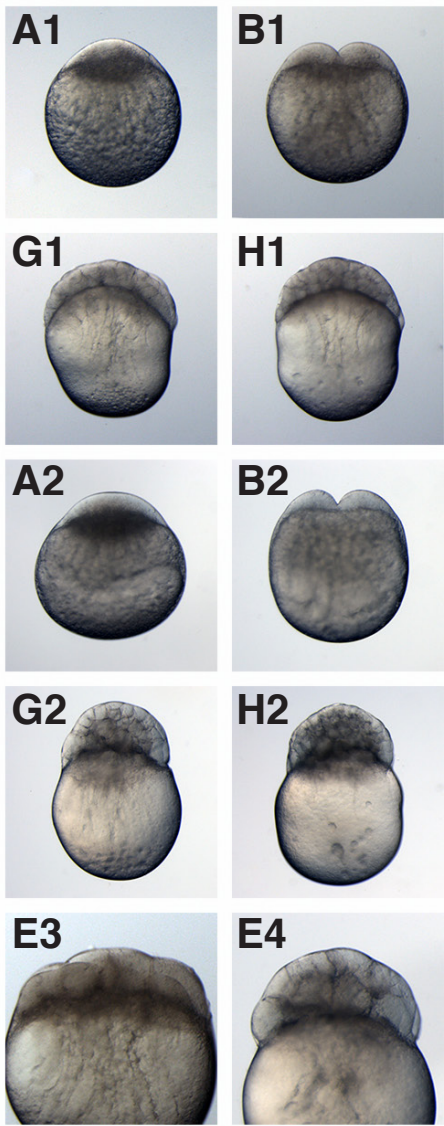

B2
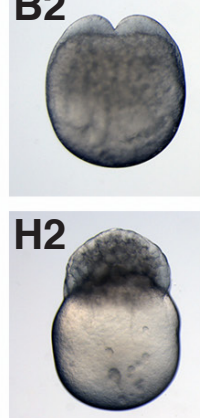

E4

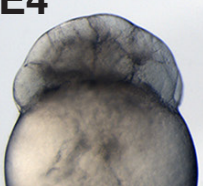

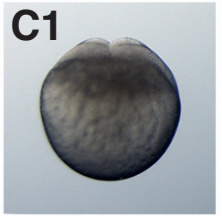

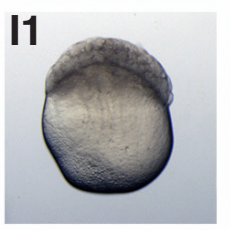

C2

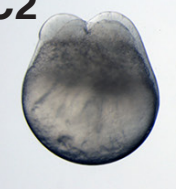

12

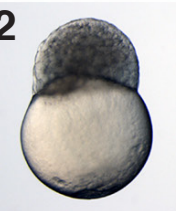

F3

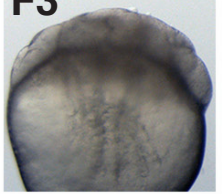

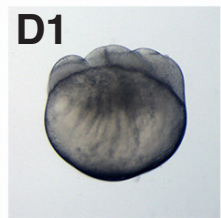

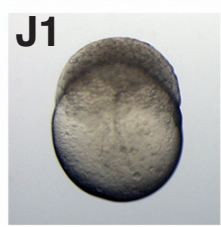

D2
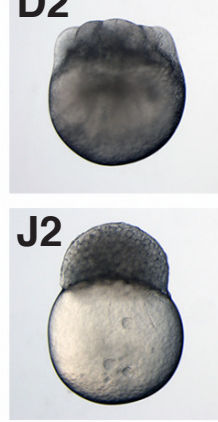

F4

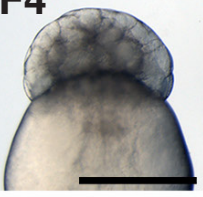

furrows (Otani et al., 2002, Saito et al., 2004, Yoon et al., 1997). In zebrafish, the germplasm may be visualized by injection with artificial GFP-buc mRNA (Bontems et al., 2009). Therefore, the present results show that the germplasm in goldfish aggregates at the boundaries between the lower and upper tiers of blastomeres,

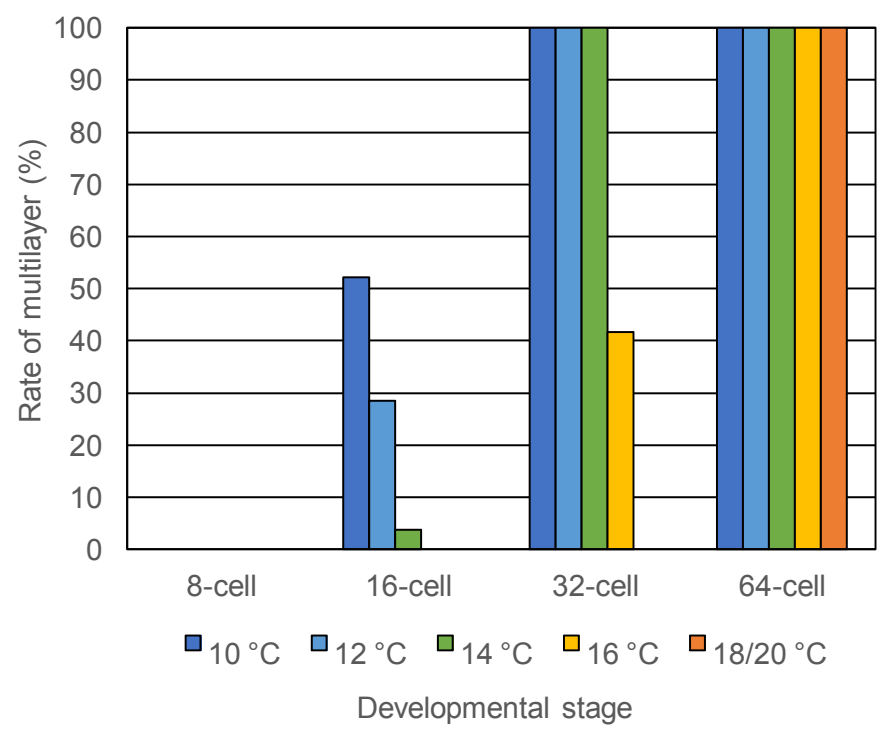

Fig. 6. Percentages of goldfish embryos in which a multilayer formed during the cleavage period, during development at temperatures ranging from 10 to $20^{\circ} \mathrm{C}$.
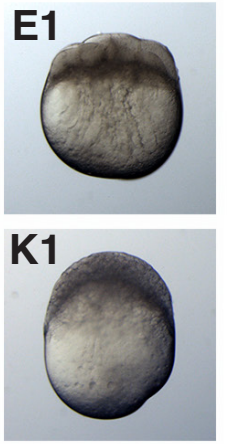

E2
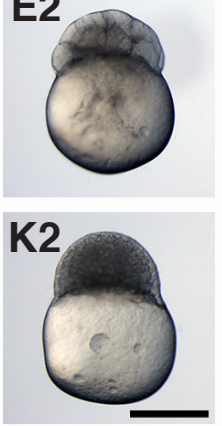

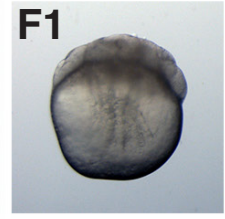

Fig. 5. (A1-K1) 3D images of the cleavage stage of goldfish embryos incubated at $20^{\circ} \mathrm{C}$. (A1) 1-cell stage (40 mpf); (B1) 2-cell stage (60 mpf); (C1) 4-cell stage (90 mpf); (D1) 8-cell stage (130 mpf); (E1) 16-cell stage (160 mpf); (F1) 32-cell stage (190 mpf): (G1) 64-cell stage (230 mpf); (H1) 128-cell stage (260 mpf); (I1) 256-cell stage (290 mpf); (J1) 512 stage (360 mpf). (A2-K2) Goldfish embryos incubated at $10^{\circ} \mathrm{C}$ during the cleavage stage. (A2) 1-cell stage; (B2) 2-cell stage (260 mpf); (C2) 4-cell stage (390 mpf); (D2) 8-cellstage (520 mpf); (E2) 16-cell stage (650 mpf); (F2) 32-cell stage (780 mpf); (G2) 64-cell stage (920 mpf); (H2) 128cell stage (1050 mpf); (I2) 256-cell stage (1180 mpf); (J2) 512-cell stage (1310 mpf); (K2) 1k-cell stage (1440 mpf). mpf, minutes post-fertilization. $(\mathbf{E} 3, \mathbf{F} 3)$ High magnification of the blastodisc with a singlelayer. (E3) High magnification of (E1). (F3) High magnification of (F1). (E4,F4) High magnification of the blastodisc with a multilayer. (E4) High magnification of (E2). (F4) High magnification of (F2). Scale bar, $500 \mu \mathrm{m}$. cell stage (320 mpf); (K1) 1 k-cell

in addition to the normal positions, at the ends of the first three cleavage furrows, under cultivation at lower temperatures. It is reported that germplasm components in zebrafish, which include dead-end, nanos1, and vasa RNAs, are initially present in a wide cortical band at the animal pole and recruited toward the blastodisc periphery by microtubule-dependent movement (Theusch et al., 2006). Low-temperature conditions may affect the movement of germplasm in goldfish embryos. As evidence in this study, mottled staining was observed in the embryos with vasa in situ hybridization. This indicated retardation of germplasm movement during the early cleavage stage, though more detailed analysis will be required.

\section{Conclusions}

Goldfish (Carassius auratus auratus) embryos are useful for embryo manipulation because of their relatively large size and tolerance to a wide temperature range. Developmental speed can be slowed by lowering the temperature, thus enabling researchers to perform complicated and delicate microsurgical operations that require long times. In addition, the round shape of blastoderms in embryos cultivated at lower temperatures enables easy handling for manipulation. Our study shows that the rate of development in goldfish embryos can be changed by altering the temperature, and the embryos are tolerant to such temperature changes. Researchers can prepare embryos of different developmental stages using a single batch of eggs simply by controlling the temperature. In addition, PGCs may increase under low-temperature cultivation, which is useful when employing techniques such as heterochronic 
A
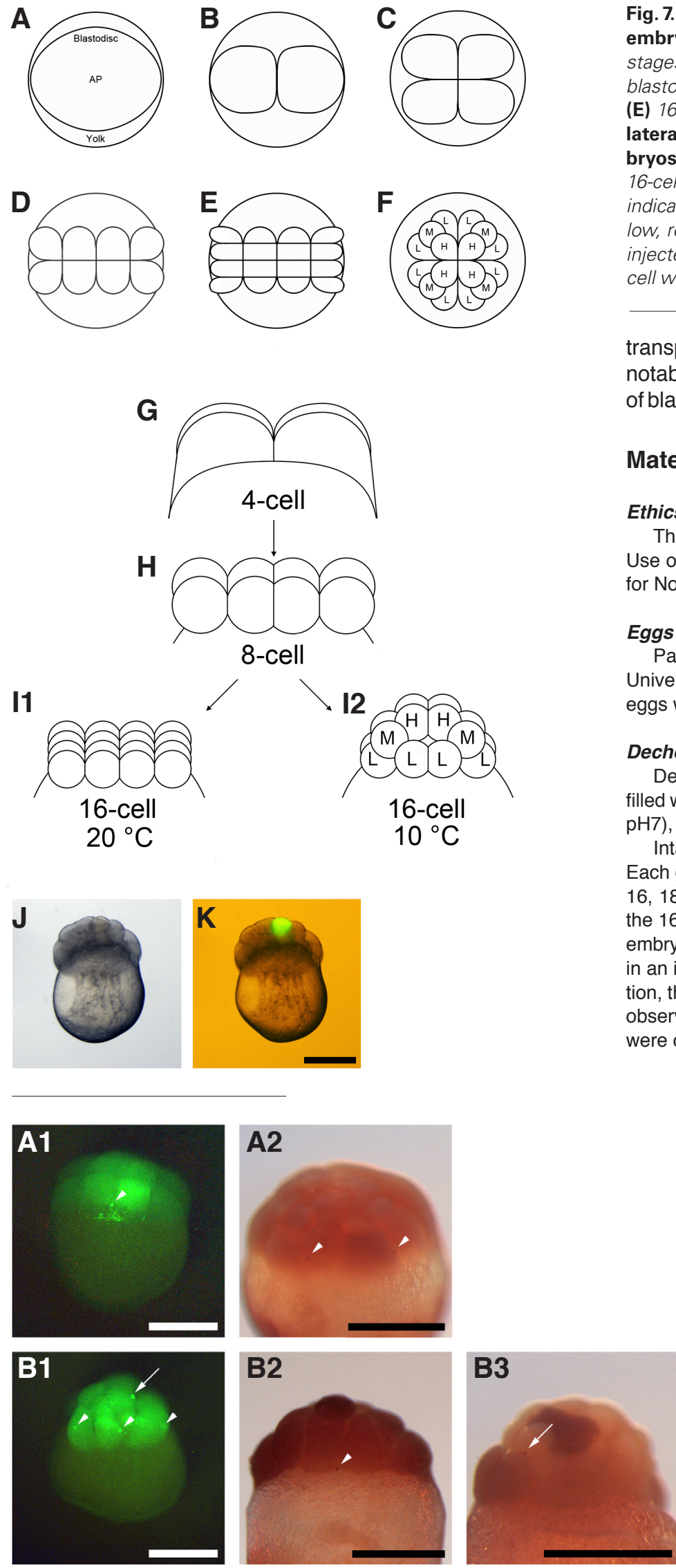

Fig. 7. (Left) Schematic illustrations of the blastomere position in goldfish embryos incubated at $10^{\circ} \mathbf{C}$ or $\mathbf{2 0}^{\circ} \mathbf{C}$. (A-F) Top view of the 1-cell to 16-cell stages. (A) Outer circle denotes the yolk, and inner ellipse the uncleaved blastodisc; AP, animal pole. (B) 2-cell stage; (C) 4-cell stage; (D) 8-cell stage; (E) 16 -cell stage, all at $20^{\circ} \mathrm{C}$; (F) 16 -cell stage at $10^{\circ} \mathrm{C}$. (G-I2) Diagrammatic lateral view of the animal pole, showing morphological changes in embryos at the 4-cell to 16 -cell stages, when incubated at $10^{\circ} \mathrm{C}$ or $20^{\circ} \mathrm{C}$. (I1) 16 -cell stage at $20^{\circ} \mathrm{C}$, and (I2) multilayered 16 -cell stage at $10^{\circ} \mathrm{C} . \mathrm{H}, \mathrm{M}$ and $\mathrm{L}$ indicate positions of the blastomeres in the blastoderm, as high, middle or low, respectively. $(\mathbf{J}, \mathbf{K})$ 16-cell stage goldfish embryo incubated at $10^{\circ} \mathrm{C}$, and injected with FITC solution at this stage; the dye was maintained in the single cell without diffusion. (J) Bright view; (K) fluorescent view. Scale bar, 500 um.

transplantation and germ-cell transplantation (Saito et al., 2010). Thus, notable embryological phenomena, such as the differentiation potency of blastomeres at early stages, can be studied using goldfish embryos.

\section{Materials and Methods}

\section{Ethics}

This study was carried out in accordance with the Guide for the Care and Use of Laboratory Animals in Hokkaido University and Field Science Center for Northern Biosphere, Hokkaido University, Japan (\#22-1).

\section{Eggs and sperm}

Parent goldfish were kept at the Nanae Freshwater Laboratory at Hokkaido University. Fish were maintained at $10-14^{\circ} \mathrm{C}$. Artificial fertilization of goldfish eggs was performed as described by Yamaha et al., (2001).

\section{Dechorionation and incubation conditions}

Dechorionated embryos were incubated in $1 \%$ agar-coated petri dishes filled with Ringer's culture solution (128 mM NaCl, $2.8 \mathrm{mM} \mathrm{KCl}, 1.8 \mathrm{mM} \mathrm{CaCl}_{2}$; $\mathrm{pH} 7$ ), plus $0.01 \%$ penicillin, $0.01 \%$ streptomycin, and $1.6 \%$ albumen.

Intact embryos and dechorionated embryos were divided into 11 groups. Each group of embryos was incubated at a different temperature $(10,12,14$, $16,18,20,22,24,26,28$ or $30^{\circ} \mathrm{C}$ ). The intact embryos were observed until the 16-cell stage to determine the exact cleavage speed. The dechorionated embryos were held in 96-well plates and kept at the designated temperature in an incubator until the embryos reached the gastrula period. After gastrulation, the temperature was altered and all embryos were kept at $20^{\circ} \mathrm{C}$ until the observations were completed. During development, any abnormal embryos were counted and removed.

\section{Measuring the shape of the embryos}

The shape of the blastodiscs were measured. At least 10 embryos were randomly selected and the height and width were measured.

\section{Description of developmental stages}

The developmental stages of the goldfish were defined using the morphological characteristics described by Tsai et al., (2013). Embryos were observed at 10 min intervals until 24 hours post-

Fig. 8. (Left) Goldfish embryo germplasm at the 16-cell stage. (A) Incubated at $20^{\circ} \mathrm{C}$; arrowheads indicate visualized germplasm in the area around the margin of the blastodisc. (B) Incubated at $10^{\circ} \mathrm{C}$; arrowheads indicate visualized germplasm in the area around the margin of the blastodisc and arrows indicate those between the upper and lower layers. (A1, B1) Germplasm visualized using green fluorescent protein (GFP) after injection with GFP-buc mRNA. (A2, B2, B3) Germplasm visualized with in situ hybridization of vasa probe. Note the blastomeres stained with a mottled pattern in B3. Scale bar, $500 \mu \mathrm{m}$. 
fertilization (hpf); at $1 \mathrm{~h}$ intervals from 24 to $48 \mathrm{hpf}$; and at $24 \mathrm{~h}$ intervals after $48 \mathrm{hpf}$. At least 20 embryos were randomly selected and observed until epiboly was completed. Following the segmentation period, at least five embryos were randomly selected for observation. After completion of epiboly, the embryonic stages were further described using embryo length (EL), head-trunk angle (HTA), otic vesicle length (OVL), pectoral-fin height (PF), and pectoral-fin height/width (H/W), based on Kimmel et al., (1995), Tsai et al., (2013).

\section{Photographing the external appearance of developing embryos}

Embryos without the chorion were incubated in petri dishes with $1 \%$ agar, in preparation for photographing. The petri dish containing the embryo was incubated on a heat plate (ThermoPlate, FTP-28190; AS ONE company, Osaka, Japan). The external appearance of each embryo was photographed using a stereoscopic microscope (Leica, MZ16F-RCFL, DFC300FX).

\section{Visualization of a single blastomere}

If the 16-cell embryos make multilayered blastoderm, a single blastomere of the 16-cell stage was labeled with fluorescein isothiocyanate conjugated with dextran (FITC-Dextran). Five percent FITC-Dextran (Sigma) solution in $0.2 \mathrm{M} \mathrm{KCl}$ was injected into a single blastomere in the animal pole and observed $10 \mathrm{~min}$ after the injection.

\section{Analyzing a germplasm localization}

Artificially synthesized GFP-buc mRNA was injected into the animal or vegetal pole of fertilized eggs to investigate the origin of PGCs, in accordance with the method of Bontems et al., (2009). Capped mRNAs were synthesized in vitro using a mMESSAGE mMACHINE® Kit (Ambion). The artificially synthesized mRNAs were dissolved in $0.2 \mathrm{M} \mathrm{KCl}$ at a concentration of $300 \mathrm{mg} / \mathrm{ml}$.

In situ hybridization of vasa mRNA was performed to analyze the localization of maternal germplasm, with slight modifications using a $0.4-\mathrm{Kb}$ fragment from the $3^{\prime}$-UTR region of vas cDNA in zebrafish as a template, in accordance with the method of Fujimoto et al., (2006). The embryos under incubation at $10^{\circ} \mathrm{C}$ and $20^{\circ} \mathrm{C}$ were fixed at the 16 - to 32 -cell stages with $4 \%$ paraformaldehyde for $10 \mathrm{~h}$.

\section{Acknowledgments}

The authors are grateful to Shizuo Kimura, Miyuki Kawashima, and members of the Nanae Freshwater Laboratory (Field Science Center for Northern Biosphere, Hokkaido University) for advice and help with the breeding of fish. Cynthia Kulongowski (MSc), with the Edanz Group (www. edanzediting.com/ac), edited a draft of this manuscript. This work was supported by JSPS KAKENHI Grant Numbers 2458163 and 24080099 (to EY).

\section{References}

ALVAREZ, J. and FADIC, R. (1992). Assembly and disassembly of axonal microtubules of the toad Xenopus laevisunder the effect of temperature. J Exp Zool264:261-266.

BEAMS, H.W., KESSEL, R.G., SHIH, C.Y. and TUNG, H.N. (1985). Scanning electron microscope studies on blastodisc formation in the zebrafish, Brachydanio rerio. J. Morphol. 184: 41-49.

BONTEMS, F., STEIN, A., MARLOW, F., LYAUTEY, J., GUPTA, T., MULLINS, M.C. and DOSCH, R. (2009). Bucky ball organizes germ plasm assembly in zebrafish. Curr Biol 19: 414-422.
FUJIMOTO, T., KATAOKA, T., SAKAO, S., SAITO, T., YAMAHA, E. and ARAI, K. (2006). Developmental stages and germ cell lineage of the loach (Misgurnus anguillicaudatus). Zoolog Sci 23: 977-989.

GOTO, R., SAITO, T., TAKEDA, T., FUJIMOTO, T., TAKAGI, M., ARAI, K. and YAMAHA, E. (2012). Germ cells are not the primary factor for sexual fate determination in goldfish. Dev Biol 370: 98-109.

IWAMATSU, T. (2004). Stages of normal development in the medaka Oryzias latipes. Mech Dev 121: 605-618.

KAZAMA-WAKABAYASHI, M., YAMAHA, E. and YAMAZAKI, F. (1999). The Elimination and Duplication of Lower Part of Blastoderm Effects on the Number of Primordial Germ Cells in Goldfish. Fisheries Sci. 65: 577-582.

KIMMEL, C.B., BALLARD, W.W., KIMMEL, S.R., ULLMANN, B. and SCHILLING, T.F. (1995). Stages of embryonic development of the zebrafish. Dev Dyn203:253-310.

MIZUNO, T., YAMAHA, E. and YAMAZAKI, F. (1997). Localized axis determinant in the early cleavage embryo of the goldfish, Carassius auratus. Dev Genes Evol 206: 389-396.

OTANI, S., MAEGAWA, S., INOUE, K., ARAI, K. and YAMAHA, E. (2002). The germ cell lineage identified by vas-mRNA during the embryogenesis in goldfish. Zoolog Sci 19: 519-526.

SAITO, T., GOTO-KAZETO, R., FUJIMOTO, T., KAWAKAMI, Y., ARAI, K. and YAMAHA, E. (2010). Inter-species transplantation and migration of primordial germ cells in cyprinid fish. Int $J$ Dev Biol 54: 1481-1486.

SAITO, T., OTANI, S., FUJIMOTO, T., SUZUKI, T., NAKATSUJI, T., ARAI, K. and YAMAHA, E. (2004). The germ line lineage in ukigori, Gymnogobius species (Teleostei: Gobiidae) during embryonic development. Int J Dev Biol48: 1079-1085.

TAKAHASHI, E., SHIMIZU, Y., URUSHIBATA, H., KAWAKAMI, Y., ARAI, K. and YAMAHA, E. (2017). Migration behavior of PGCs and asymmetrical gonad formation in pond smelt Hypomesus nipponensis. Int J Dev Biol 61: 397-405.

THEUSCH, E.V., BROWN, K.J. and PELEGRI, F. (2006). Separate pathways of RNA recruitment lead to the compartmentalization of the zebrafish germ plasm. Dev Biol 292: 129-141.

TSAI, H.Y., CHANG, M., LIU, S.C., ABE, G. and OTA, K.G. (2013). Embryonic development of goldfish (Carassius auratus): a model for the study of evolutionary change in developmental mechanisms by artificial selection. Dev Dyn 242: 1262-1283.

WAKAMATSU, Y. (2008). Novel method for the nuclear transfer of adult somatic cells in medaka fish (Oryzias latipes): use of diploidized eggs as recipients. Dev Growth Differ 50: 427-436.

YAMAHA, E., KAZAMA-WAKABAYASHI, M., OTANI, S., FUJIMOTO, T. and ARAI, K. (2001). Germ-line chimera by lower-part blastoderm transplantation between diploid goldfish and triploid crucian carp. Genetica 111: 227-236.

YAMAHA, E., MIZUNO, T., HASEBE, Y., TAKEDA, H. and YAMAZAKI, F. (1998). Dorsal specification in blastoderm at the blastula stage in the goldfish, Carassius auratus. Dev Growth Differ 40: 267-275.

YAMAHA, E., MIZUNO, T., MATSUSHITA, K. and HASEBE, Y. (1999). Developmental Staging in Goldfish during the Pre-gastrula Stage. Nippon Suisan Gakkaishi 65: 709-717.

YAMAHA, E., MURAKAMI, M., HADA, K., OTANI, S., FUJIMOTO, T., TANAKA, M., SAKAO, S., KIMURA, S., SATO, S. and ARAI, K. (2003). Recovery of fertility in male hybrids of a cross between goldfish and common carp by transplantation of PGC (primordial germ cell)-containing graft. Genetica 119: 121-131.

YAMAHA, E., OTANI, S., MINAMI, A. and ARAI, K. (2002). Dorsoventral axis perturbation in goldfish embryos caused by heat and pressure-shock treatments for chromosome set manipulation. Fisheries Sci. 68: 313-319.

YOON, C., KAWAKAMI, K. and HOPKINS, N. (1997). Zebrafish vasa homologue RNA is localized to the cleavage planes of 2- and 4-cell-stage embryos and is expressed in the primordial germ cells. Development 124: 3157-3165. 


\section{Further Related Reading, published previously in the Int. J. Dev. Biol.}

Preparation of a fish embryo for micromanipulation: staging of development, removal of the chorion and traceability of PGCs in Prochilodus lineatus

Geovanna C.Z. Coelho, Isaac S. Yo, Tatiana M. Mira-López, Paulo S. Monzani, Dilberto R. Arashiro, Takafumi Fujimoto, José A. Senhorini and George S. Yasui

Int. J. Dev. Biol. (2019) 63: 57-65

https://doi.org/10.1387/ijdb.180348gc

Inter-species transplantation and migration of primordial germ cells in cyprinid fish

Taiju Saito, Rie Goto-Kazeto, Takafumi Fujimoto, Yutaka Kawakami, Katsutoshi Arai and Etsuro Yamaha

Int. J. Dev. Biol. (2010) 54: 1481-1486

https://doi.org/10.1387/ijdb.103111ts

Developmental potential of embryonic cells in a nucleocytoplasmic hybrid formed using a goldfish haploid nucleus and loach egg cytoplasm

Takafumi Fujimoto, Taiju Saito, Suzu Sakao, Katsutoshi Arai and Etsuro Yamaha

Int. J. Dev. Biol. (2010) 54: 827-835

https://doi.org/10.1387/ijdb.092896tf

The formation of primordial germ cells from germline cells in spherical embryos derived from the blastodisc of 2-cell embryos in goldfish, Carassius auratus

Satoshi Otani, Tomoe Kitauchi, Taiju Saito, Suzu Sakao, Shingo Maegawa, Kunio Inoue, Katsutoshi Arai and Etsuro Yamaha

Int. J. Dev. Biol. (2005) 49: 843-850

http://www.intjdevbiol.com/web/paper/052027so

Electrically fused-egg induction and its development in the goldfish, Carassius auratus E Yamaha and F Yamazaki

Int. J. Dev. Biol. (1993) 37: 291-298

http://www.intjdevbiol.com/web/paper/8398675

Developmental incompatibility between cell nucleus and cytoplasm as revealed by nuclear transplantation experiments in teleost of different families and orders S Y Yan, M Tu, H Y Yang, Z G Mao, Z Y Zhao, L J Fu, G S Li, G P Huang, S H Li and G Q Jin Int. J. Dev. Biol. (1990) 34: 255-266

http://www.intjdevbiol.com/web/paper/2386727

Mitochondrial DNA content and mitochondrial gene transcriptional activities in the early development of loach and goldfish

G Wang and $S$ Yan

Int. J. Dev. Biol. (1992) 36: 477-482

http://www.intjdevbiol.com/web/paper/1338287

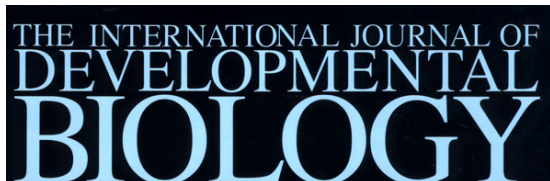

Volume 41 No. 2

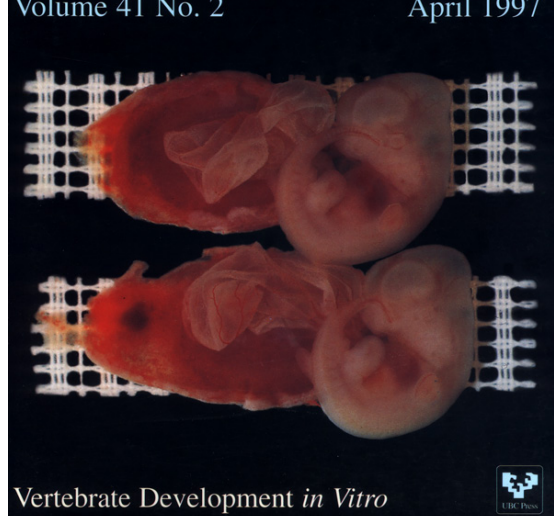

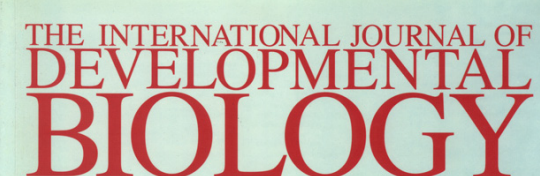

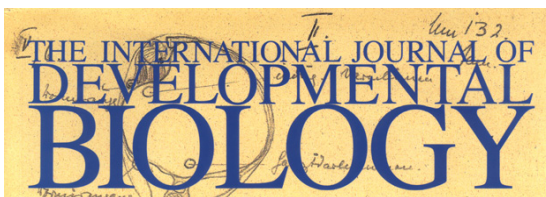

Volume 45 No. 1 Special issue
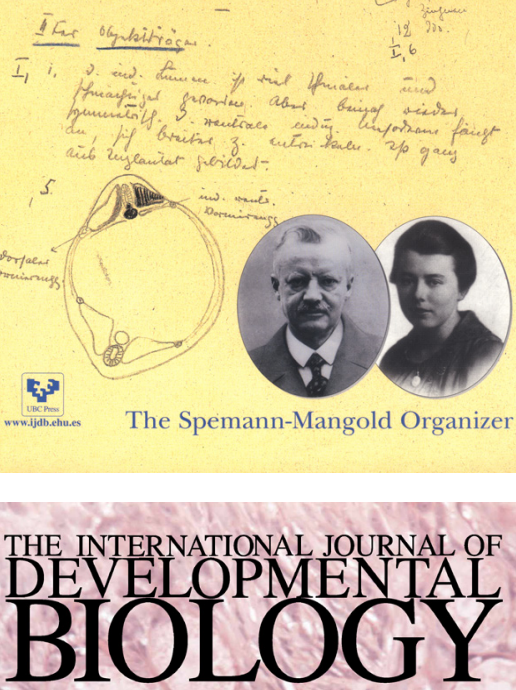

Volume 45 No. 3 Special issue

Volume 40 No. 4 August 1996

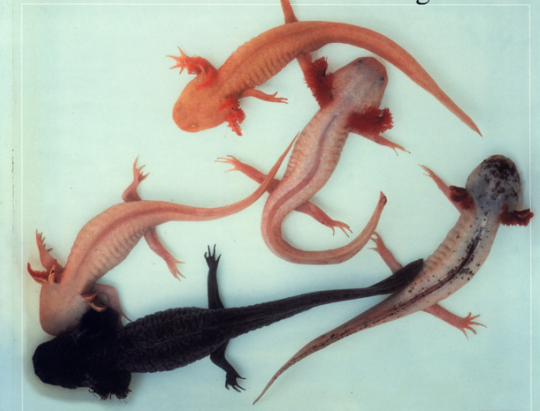

Developmental Biology of Urodeles

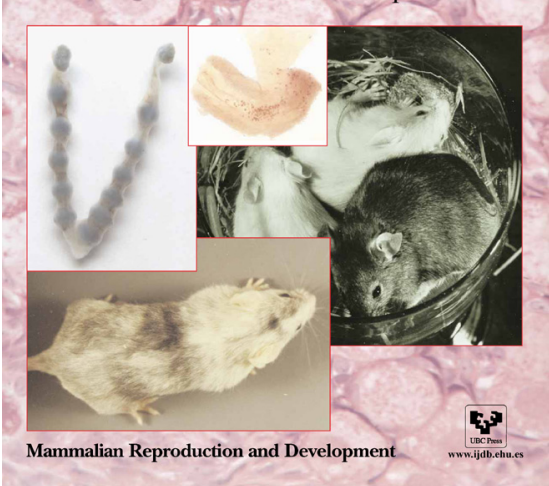

